\title{
Metaplastic carcinoma of the breast and BRCA1 germline mutation: a case report and review
}

\author{
Michiko Yamashita ${ }^{1,2}$, Yoshiaki Kamei ${ }^{1,2^{*}}$, Akari Murakami ${ }^{1,2}$, Erina Ozaki ${ }^{3}$, Kumiko Okujima ${ }^{1,2}$, Kana Takemoto ${ }^{1,2}$, \\ Megumi Takaoka ${ }^{1,2}$, Daiki Tsukamoto ${ }^{1,2}$, Erina Kusakabe ${ }^{1,2}$, Tomoyuki Shidahara $^{1,2}$, Haruna Noda ${ }^{1,2}$, Reina Aoki ${ }^{1,2}$, \\ Kana Taguchi ${ }^{1,2}$, Kanako Nishiyama ${ }^{1,2}$, Mariko Eguchi $^{4}$ and Yasutsugu Takada ${ }^{2}$
}

\begin{abstract}
Background: Metaplastic carcinoma of the breast consists of both invasive ductal carcinoma and metaplastic carcinoma. This rare subtype of cancer has a poor prognosis. The development of metaplastic breast cancer and relationship with BRCA1 are not well known. Here, we report a rare case of germline BRCA1 mutation-positive breast cancer with chondroid metaplasia.

Case presentation: A 39-year-old Japanese woman with a family history of breast cancer in her mother and ovarian cancer in her maternal grandmother consulted at our hospital with a left breast mass. Needle biopsy for the mass was performed, leading to a diagnosis of invasive breast cancer with chondroid metaplasia. We performed left mastectomy + sentinel lymph node biopsy + tissue expander insertion and replaced with a silicone implant later. Pathological examination revealed that the patient had triple-negative breast cancer. Four courses of doxorubicin+ cyclophosphamide therapy were performed as adjuvant therapy after surgery. We performed genetic counseling and genetic testing, and the results suggested the germline BRCA1 mutation $307 \mathrm{~T}>\mathrm{A}\left(\mathrm{L} 63^{*}\right)$. She has currently lived without a relapse for 2 years post-surgery.

Conclusions: There have been only 6 cases of metaplastic breast carcinoma with germline BRCA1 mutations including our case. Patients with BRCA1 mutations may develop basal-like subtypes or M type of triple-negative breast cancer besides metaplastic breast cancers.
\end{abstract}

Keywords: Chondroid metaplasia, BRCA1 mutation, Triple-negative breast cancer

\section{Background}

Most germline BRCA mutation-positive breast cancers are invasive ductal carcinoma of the non-special type; the frequency of special types, such as metaplastic carcinoma, is low. Here, we report a rare case of gBRCA1 mutationpositive breast cancer with chondroid metaplasia and

\footnotetext{
* Correspondence: yoshkam@m.ehime-u.ac.jp

'Department of Breast Center, Ehime University Hospital, Shitsukawa, Toon, Ehime, Japan

${ }^{2}$ Department of Hepato-Biliary-Pancreatic Surgery and Breast Surgery, Ehime University Graduate School of Medicine, Shitsukawa, Toon, Ehime, Japan Full list of author information is available at the end of the article
}

review the literature on gBRCA1 mutation-positive metaplastic carcinoma of the breast.

\section{Case presentation}

A 39-year-old woman with a family history of breast cancer in her mother and ovarian cancer in her maternal grandmother noticed a lump in her left breast and consulted her primary care doctor. Because of the examination, the possibility of breast cancer was considered, and she was referred to our hospital for detailed examination.

(c) The Author(s). 2021 Open Access This article is licensed under a Creative Commons Attribution 4.0 International License, which permits use, sharing, adaptation, distribution and reproduction in any medium or format, as long as you give appropriate credit to the original author(s) and the source, provide a link to the Creative Commons licence, and indicate if changes were made. The images or other third party material in this article are included in the article's Creative Commons licence, unless indicated otherwise in a credit line to the material. If material is not included in the article's Creative Commons licence and your intended use is not permitted by statutory regulation or exceeds the permitted use, you will need to obtain permission directly from the copyright holder. To view a copy of this licence, visit http://creativecommons.org/licenses/by/4.0/ The Creative Commons Public Domain Dedication waiver (http://creativecommons.org/publicdomain/zero/1.0/) applies to the data made available in this article, unless otherwise stated in a credit line to the data. 
A 1.4-cm tumor was palpated in the upper-outer region of left breast, an enlarged lymph node was not palpated, and there was no nipple discharge.

According to mammography (Fig. 1), an equal density mass with a margin showing a circumscribed irregular shape was observed in the outer upper quadrant of the left breast at one o'clock in the anterior portion, and calcification was found inside of the mass. By ultrasonography, a $1.4 \times 1.4 \times 1.0-\mathrm{cm}$ clear and rough, microlobulated marginal heterogeneous mass was observed in the outer upper quadrant of the left breast, along with calcification and enhanced posterior features (Fig. 2b).

Invasive ductal carcinoma and adjacent chondroid metaplastic breast cancer were diagnosed by needle biopsy. Positron emission spectroscopy-computed tomography revealed a tumor of maximum standardized uptake value of 7.7 in the outer upper quadrant of the left breast, with no lymph node metastasis or distant metastasis.

Based on these results, we diagnosed the patient with left breast cancer, cT1cN0M0, Stage I.

We performed left mastectomy + sentinel lymph node biopsy + tissue expander insertion as well as silicone implant replacement surgery approximately 6 months later.

In the outer upper quadrant of the whole breast resection specimen, $1.5 \mathrm{~cm}$ of metaplastic carcinoma (Fig. 3a), a component of chondroid metaplasia (Fig. 3b), and a component of ductal carcinoma (Fig. 3c) were mixed. Breast cancer invaded the fat tissue, the nuclear grade was 3 (atypia: 3, mitosis: 3 ), and the surgical margin was negative. Lymph node metastasis was not observed. The results of immunohistochemistry analysis were as follows: estrogen receptor: negative $(0 \%)$, progesterone receptor: negative (0\%), HER-2: negative (0), and MIB-1 index: $70-80 \%$. These results suggested triple-negative breast cancer (TNBC).

As a postoperative course, we conducted genetic counseling because of the young onset of TNBC with a family history of both breast cancer and ovarian cancer. She wished to undergo genetic testing, and thus we evaluated $B R C A 1$ and BRCA2. The results confirmed the presence of the pathogenic mutation c. 188 T>A (L63*) in BRCA1. Four courses of doxorubicin + cyclophosphamide therapy were performed as postoperative adjuvant chemotherapy. In addition, after disclosing the genetic test results, periodic surveillance of ovarian cancer was started. She did not want to undergo contralateral mastectomy; therefore, surveillance of the contralateral breast was started. The patient has asthma and cannot be evaluated by contrast-enhanced magnetic resonance imaging, and thus mammography and ultrasonography are performed once per year. Currently, she has been alive without relapse for 2 years post-surgery.

\section{Discussion and conclusions}

Metaplastic carcinoma includes a group of tumors in which adenocarcinoma has caused "metaplasia" to differentiate into the squamous epithelium, mesenchymal component, spindle cell, cartilage, bone, and others [1].

The frequency of metaplastic carcinoma in breast cancer is reported to be approximately $1 \%$, making this

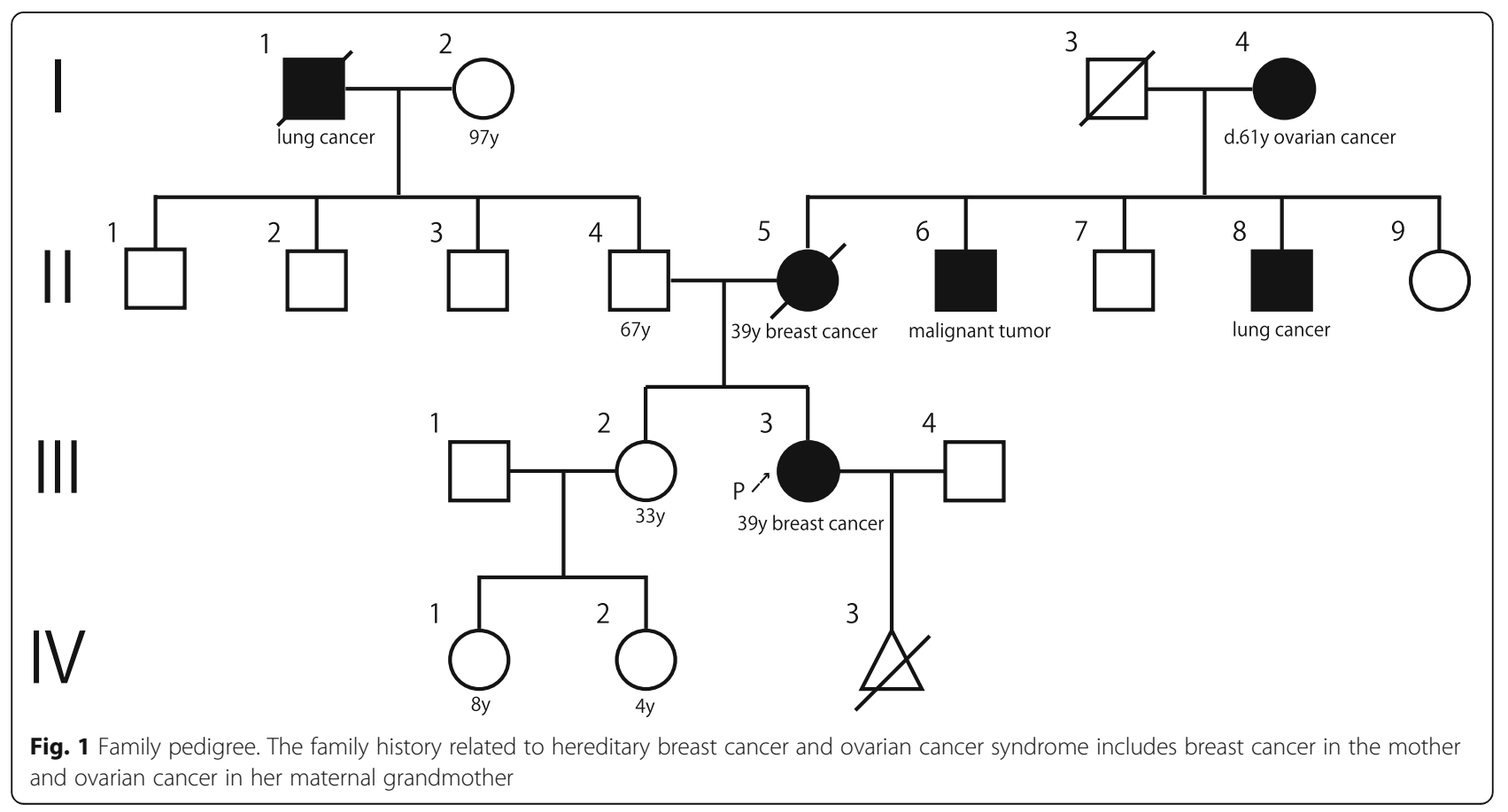


a)

b) c)
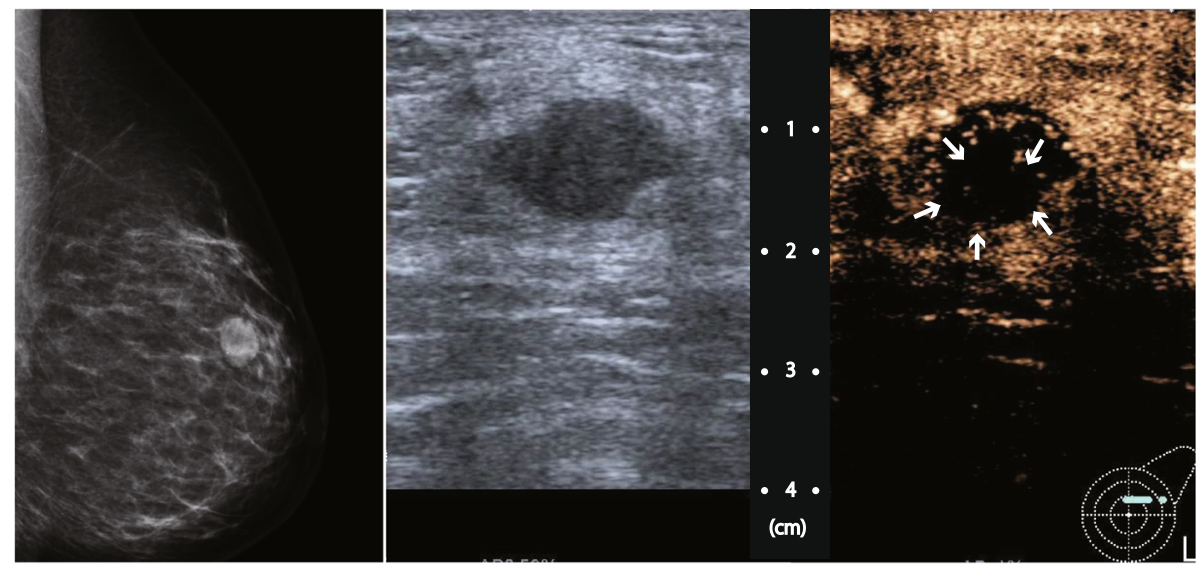

Fig. 2 Imaging results. a Mammography; an equal density mass with calcification. b Ultrasound; a 1.4-cm microlobulated heterogeneous mass. c Contrast-enhanced ultrasound; arrows indicate contrast loss area

condition quite rare [1]. Almost all metaplastic breast cancers are classified as TNBC [2].

Approximately $80-90 \%$ of breast cancers developed in carriers with pathological mutations in $g B R C A 1$ are classified as the basal-like subtype in the gene expression profile, most of which show characteristics of TNBC [3]. Based on this, Perou et al. reported that BRCA1 is frequently observed in different stages of epithelial cell development; a $B R C A 1$ mutation is linked to this luminal progenitor/basallike phenotype, and loss of BRCA1 may block further differentiation and retain a cell in this stage of development [4].

Our case and only 5 other cases have been reported according to PubMed, showing that a gBRCA1 mutationpositive status may lead to metaplastic cancer development [5-8].

All six cases were TNBC; however, the $B R C A 1$ mutation site and tissue type of metaplastic carcinoma differed
(Table 1). In previous reports, gBRCA1 mutation-positive metaplastic carcinomas included carcinosarcoma in 2 cases, osseous and chondroid metaplasia in 1 cases, squamous cell carcinoma in 1 case, and adenosquamous carcinoma in 1 case. A case of osseous and chondroid metaplasia was examined for breast cancer tissue at the Foundation One $\mathrm{CDx}$ and it is unclear whether it is a germ line mutation or a somatic mutation [9]. Another case of BRCA1 mutationpositive metaplastic breast carcinoma was reported many years ago [10] but a search in the current database revealed that the mutations were not pathogenic.

Recently, in subtype classification based on the gene expression profile, TNBC was divided into four subtypes: BL1, BL2, M, and LAR [11]. BL1 and BL2 are characterized by the expression of genes related to the cell cycle and DNA damage response and are cisplatin-sensitive in cell lines.

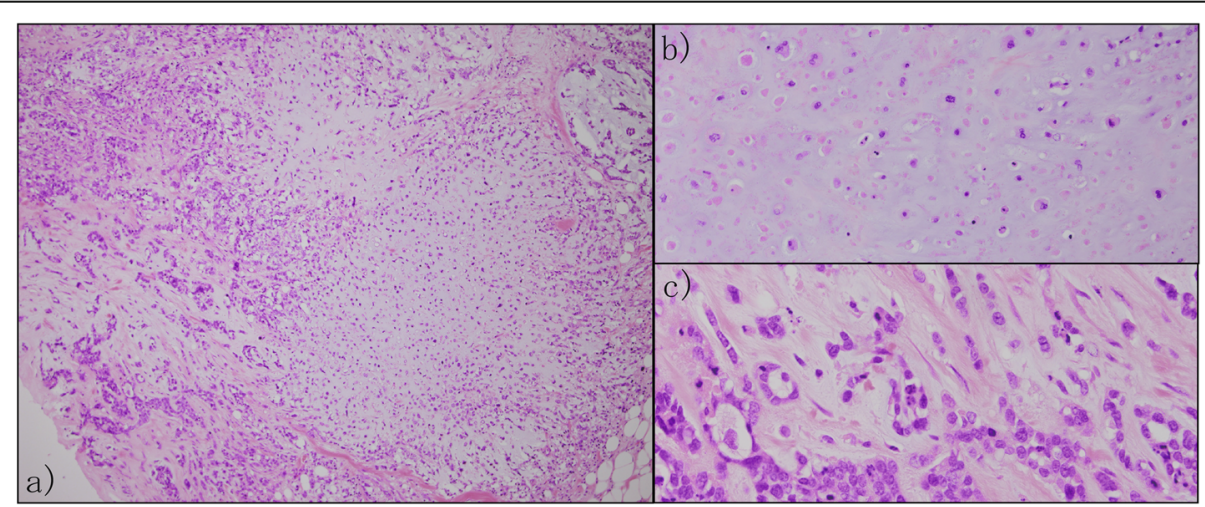

Fig. 3 Pathological findings. a Low-magnification image ( $\times 10)$; bright part on the right area is a metaplastic carcinoma component containing cartilage matrix, and the part with a large number of nuclei on the left area is a ductal carcinoma component. $\mathbf{b}$ High-magnification image: metaplastic carcinoma lesion ( $\times 20)$; component of metaplastic carcinoma, type of chondroid metaplasia. $\mathbf{c}$ High-magnification image: ductal carcinoma lesion $(\times 40)$; component of ductal carcinoma, strong atypia, and mitosis in the nuclei 
Table 1 Reported cases

\begin{tabular}{|c|c|c|c|c|c|}
\hline & Age & Family history & $\begin{array}{l}\text { BRCA1 } \\
\text { mutation }\end{array}$ & Subtype & Pathological type \\
\hline $\begin{array}{l}\text { Rashid et al } \\
{[5] .}\end{array}$ & 22 & none & $\begin{array}{l}\text { c.66_67 } \\
(\mathrm{E} 23 \mathrm{fs})\end{array}$ & TNBC & carcinosarcoma \\
\hline Noel et al [6]. & 49 & none & $\begin{array}{l}\text { c.66dupA } \\
\text { (E23fs) }\end{array}$ & TNBC & adenosquamous carcinoma \\
\hline $\begin{array}{l}\text { Suspitsin et al } \\
\text { [7]. }\end{array}$ & 35 & $\begin{array}{l}\text { mother } 52 \text { years } \\
\text { ovarian cancer }\end{array}$ & $\begin{array}{l}\text { C.5266dupC } \\
\text { (Q1756fs) }\end{array}$ & TNBC & carcinosarcoma \\
\hline $\begin{array}{l}\text { Breuer et al } \\
\text { [8]. }\end{array}$ & 25 & two paternal aunts 40 years or younger breast cancer & $\begin{array}{l}\text { C. } 181 \mathrm{~T}>\mathrm{G} \\
(\mathrm{C} 61 \mathrm{G})\end{array}$ & TNBC & squamous cell carcinoma \\
\hline $\begin{array}{l}\text { Hamad et al } \\
{[9] .}\end{array}$ & 54 & none & (G511fs) & TNBC & $\begin{array}{l}\text { osseous and chondroid } \\
\text { metaplasia }\end{array}$ \\
\hline our case & 39 & $\begin{array}{l}\text { mother } 39 \text { years breast cancer, maternal grandmother } 61 \text { years } \\
\text { ovarian cancer }\end{array}$ & $\begin{array}{l}\text { C. } 188 \mathrm{~T}>\mathrm{A} \\
\left(\mathrm{L} 63^{*}\right)\end{array}$ & TNBC & chondroid metaplasia \\
\hline
\end{tabular}

Five cases of metaplastic carcinoma of the breast with germline mutations in BRCA1 were reported. There were 2 cases of carcinosarcoma, 1 cases of osseous and chondroid metaplasia, 1 case of squamous cell carcinoma, and 1 case of adenosquamous carcinoma

$M$ is characterized by epithelial mesenchymal transition-related gene expression, the expression of genes involved in the growth factor pathway, and sensitivity to the PI3K/mTOR inhibitor NVP-BEZ235 and the $\mathrm{abl} / \mathrm{src}$ inhibitor dasatinib. The LAR subtype is characterized by an androgen receptor signal and is sensitive to the AR antagonist bicalutamide.

In a previous report, among the 10 patients with $B R C A$ mutation in the TNBC subtype of breast cancer, 3 cases were reported for BL1, 4 for BL2, and 3 for $M$ [12]. In another report, among the 28 metaplastic cancers, 12 cases were reported for M, 1 for BL1, 2 for BL2, and the 4 for MSL (currently, MSL is reclassified as BL or $\mathrm{M}$ ), and 9 for unstable/unknown. The results of these two studies suggested that TNBC with $B R C A$ germline mutation and metaplastic breast cancer are the same subtype, BL1, BL2, or M type TNBC [13].

Patients with BRCA1 mutations may develop basal-like subtypes or the $M$ type of TNBC, in addition to metaplastic breast cancers. There are no reports of LAR type breast cancer in either gBRCA1 mutation-positive breast cancer or metaplastic breast cancer, suggesting that the disease is another strain.

In addition, according to gene expression analysis of somatic cells from patients with metaplasia breast cancer, the BRCAness signature is found in $5 / 8$ of squamous cell carcinoma cases, $2 / 8$ of chondroid metaplasia cases, and 1/10 spindle cell carcinoma case.

The BRCAness signature differed depending on the type of metaplastic carcinoma.

Thus, gBRCA1 mutations cause metaplastic breast carcinomas, particularly chondroid metaplastic carcinomas, carcinosarcoma, and squamous cell carcinomas.

Only 6 cases of gBRCA1 mutation-positive metaplastic breast carcinoma have been reported; however, based on developmental hypotheses and the results of gene expression analysis, gBRCA1 mutations may be found in patients with metaplastic carcinoma at rates at least as high as those in TNBC. To determine the relationship between metaplastic carcinoma of the breast and pathogenic mutations in BRCA1, investigation of additional cases is necessary.

\section{Abbreviations}

germline BRCA: gBRCA; TNBC: Triple-negative breast cancer

\section{Acknowledgments \\ We are grateful to Dr. Atsurou Sugita and Dr. Yousuke Mizuno for helpful preparation of pathological data.}

\section{Authors' contributions}

Michiko Yamashita wrote the initial draft of the manuscript. Kamei Yoshiaki contributed to interpretation of data and assisted in the preparation of the manuscript. All other authors have contributed to data collection and interpretation, and critically reviewed the manuscript. All authors approved the final version of the manuscript and agree to be accountable for all aspects of the work in ensuring that questions related to the accuracy or integrity of any part of the work are appropriately investigated and resolved.

Funding

This work was supported by JSPS KAKENHI Grant Number 19 K16715.

Availability of data and materials

All data generated or analyzed during this study are included in this published article.

Ethics approval and consent to participate

This study was approved by the Ehime University Clinical Research Ethics Committee (Permit Number: 1501005).

Consent for publication

Written consent for publication of the case was obtained from the patient

\section{Competing interests}

The authors declare that they have no competing interests.

\section{Author details}

'Department of Breast Center, Ehime University Hospital, Shitsukawa, Toon, Ehime, Japan. ${ }^{2}$ Department of Hepato-Biliary-Pancreatic Surgery and Breast Surgery, Ehime University Graduate School of Medicine, Shitsukawa, Toon, Ehime, Japan. ${ }^{3}$ Department of Total Medical Support Center, Ehime University Hospital, Shitsukawa, Toon, Ehime, Japan. ${ }^{4}$ Department of Pediatrics, Ehime University Graduate School of Medicine, Shitsukawa, Toon, Ehime, Japan. 
Received: 6 June 2020 Accepted: 22 December 2020

Published online: 06 January 2021

References

1. Lakhani SR, Ellis IO, Schnitt SJ, Tan PH, Van de Vijver MJ. WHO classification of tumours of the breast. 4th ed: International Agency for Research on Cancer: Lyon; 2012.

2. Weigelt B, Ng CK, Shen R, Popova T, Schizas M, Natrajan R, et al. Metaplastic breast carcinomas display genomic and transcriptomic heterogeneity [corrected]. Mod Pathol. 2015;28:340-51.

3. Sorlie T, Tibshirani R, Parker J, Hastie T, Marron JS, Nobel A, et al. Repeated observation of breast tumor subtypes in independent gene expression data sets. Proc Natl Acad Sci U S A. 2003;100:8418-23.

4. Perou CM. Molecular stratification of triple-negative breast cancers. Oncologist. 2010;15(Suppl 5):39-48.

5. Rashid MU, Shah MA, Azhar R, Syed AA, Amin A, Hamann U. A deleterious BRCA1 mutation in a young Pakistani woman with metaplastic breast carcinoma. Pathol Res Pract. 2011;207(9):583-6.

6. Noel JC, Buxant F, Engohan-Aloghe C. Low-grade adenosquamous carcinoma of the breast-a case report with a BRCA1 germline mutation. Pathol Res Pract. 2010;206:511-3.

7. Suspitsin EN, Sokolenko AP, Voskresenskiy DA, Ivantsov AO, Shelehova KV, Klimashevskiy VF, et al. Mixed epithelial/mesenchymal metaplastic carcinoma (carcinosarcoma) of the breast in BRCA1 carrier. Breast Cancer. 2011;18:137-40.

8. Breuer A, Kandel M, Fisseler-Eckhoff A, Sutter C, Schwaab E, Luck H, et al. BRCA1 germline mutation in a woman with metaplastic squamous cell breast cancer. Onkologie. 2007:30:316-8.

9. Hamad L, Khoury T, Vona K, Nestico J, Opyrchal M, Salerno KE. A case of metaplastic breast cancer with prolonged response to single agent liposomal doxorubicin. Cureus. 2016;8(1):e454.

10. Bellino R, Arisio R, D'Addato F, Attini R, Durando A, Danese S, et al Metaplastic breast carcinoma: pathology and clinical outcome. Anticancer Res. 2003;23(1B):669-73.

11. Lehmann BD, Jovanovic B, Chen X, Estrada MV, Johnson KN, Shyr Y, et al. Refinement of triple-negative breast cancer molecular subtypes: implications for neoadjuvant chemotherapy selection. PLoS One. 2016;11: e0157368.

12. Echavarria I, Lopez-Tarruella S, Picornell A, Garcia-Saenz JA, Jerez Y, Hoadley $K$, et al. Pathological response in a triple-negative breast cancer cohort treated with neoadjuvant carboplatin and docetaxel according to Lehmann's refined classification. Clin Cancer Res. 2018:24:1845-52.

13. Weigelt B, Kreike B, Reis-Filho JS. Metaplastic breast carcinomas are basallike breast cancers: a genomic profiling analysis. Breast Cancer Res Treat. 2009;117:273-80

\section{Publisher's Note}

Springer Nature remains neutral with regard to jurisdictional claims in published maps and institutional affiliations.

Ready to submit your research? Choose BMC and benefit from:

- fast, convenient online submission

- thorough peer review by experienced researchers in your field

- rapid publication on acceptance

- support for research data, including large and complex data types

- gold Open Access which fosters wider collaboration and increased citations

- maximum visibility for your research: over $100 \mathrm{M}$ website views per year

At $\mathrm{BMC}$, research is always in progress.

Learn more biomedcentral.com/submissions 